\title{
Mediating autonomy: an essential care practice in mental health
}

\author{
Mediar a autonomia: um cuidado essencial em saúde mental \\ Mediación de la Autonomía: un cuidado esencial en salud mental
}

Virginia Faria Damásio Dutra ${ }^{1}$ Hercules Rigoni Bossato ${ }^{1}$ Rosane Mara Pontes de Oliveira ${ }^{1}$

1. Federal University of Rio de Janeiro. Rio de Janeiro, Rio de Janeiro. Brazil
Corresponding author:

Virginia Faria Damásio Dutra

E-mail: virginia.damasio@gmail.com

Submitted on 10/03/2016

Accepted on 02/27/2017.

DOI: 10.1590/2177-9465-EAN-2016-0284

\begin{abstract}
Objectives: Identify psychiatric nursing practices in the mediation of autonomy for social individuals compromised by their psychiatric history, and analyze psychiatric nursing practices focused on the autonomy of individuals who attend a type III psychosocial care center. Method: Convergent-care research using observation and semi-structured interviews with seven RN nurses from a psychosocial care center and four educational groups in the year 2013. Data analysis used social constructivism as its foundation. Results: Autonomy is presented as a care action that enables users to be the protagonists of their own lives, recognizing their limits and possibilities. Even with mental conditions, patients' potentialities must be recognized. Conclusion: Nurses invest in autonomy and liberty as foundations of care to be stimulated, mediated, or negotiated. Implications for practice: The inclusion of "autonomy mediating" as a care action for patients is emphasized.
\end{abstract}

Keywords: Psychiatric Nursing; Community Mental Health Services; Mental Health; Nursing Care; Personal Autonomy.

\section{Resumo}

Objetivos: Identificar as práticas da Enfermagem Psiquiátrica na mediação da autonomia de sujeitos sociais comprometidos pela sua história psiquiátrica e analisar as práticas da Enfermagem Psiquiátrica voltadas para a autonomia dos sujeitos que frequentam um Centro de Atenção Psicossocial III. Método: Pesquisa Convergente-Assistencial, com observação, entrevista semiestruturada com os sete enfermeiros de um Centro de Atenção Psicossocial e quatro Grupos Educativos, no ano de 2013. A análise dos dados sustentou-se no Construcionismo Social. Resultados: A autonomia apresenta-se como um cuidado que possibilita ao usuário ser o protagonista da sua vida, reconhecendo seus limites e suas possibilidades. Mesmo com o transtorno mental as potencialidades dos usuários devem ser reconhecidas. Conclusão: Os enfermeiros apostam na autonomia e na liberdade como fundamento do cuidado que poderão ser estimulada, mediada ou negociada. Implicações para a prática: Reforça-se a inclusão de "mediar a autonomia" como uma ação de cuidado aos usuários.

Palavras-chave: Enfermagem Psiquiátrica; Serviços Comunitários de Saúde Mental; Saúde Mental; Cuidados de Enfermagem; Autonomia Pessoal.

\section{Resumen}

Objetivos: Identificar prácticas de la Enfermería Psiquiátrica para a aumentar la autonomía de los individuos comprometidos por sus antecedentes psiquiátricos, y analizar las prácticas de enfermería psiquiátrica orientada para la autonomía de las personas que vaya a un Centro de Atención Psicosocial III. Método: Investigación Convergente-Assitencial mediante observación y entrevista con siete enfermeras graduadas trabajando en un centro de atención psicosocial y com cuatro grupos educativos en el año 2013. Análisis de los datos utiliza el constructivismo social. Resultados: La autonomía se presenta como una solícita acción que permitió ser protagonista de su propia vida, reconociendo sus limitaciones y posibilidades, también en la enfermedad el potencialidades deben ser reconocidas. Conclusión: Las enfermeras hacem invertsiones en la autonomía y la libertad, como una base de cuidado para ser estimulado, mediado o negociado. Implicaciones para la práctica: La inclusión del "mediar la autonomia" se reitera como una acción de cuidados.

Palabras claves: Enfermería Psiquiátrica; Servicios Comunitarios de Salud Mental; Salud Mental; Atención de Enfermería; Autonomía Persona. 


\section{INTRODUCTION}

It is important to emphasize that having a history of mental disorders and of psychiatric treatment for persons associated with the mental health services interferes with their autonomy. Autonomy ${ }^{1}$ is a concept that determines individuals' liberty to freely manage their lives, rationally making their own choices.

It is worth noting that the results of studies that employ convergent-care research (CCR) demonstrate that autonomy is not absolute independence, but a relative participation of health professionals in the collective construction of this phenomenon. ${ }^{1}$ The concept of autonomy is created through various theoretical and philosophical perspectives; therefore, the choice of these perspectives will depend on how they will be researched. In this study, we will employ the concept of "mediated autonomy," which is how nursing professionals support people under psychic distress in making choices independently, so that they are not hampered by their illness.

It is known that in the height of the institutionalization era the mentally ill were treated like robots and institutionalized. Therefore, they were not expected to think or act, because they were under guardianship; in other words, they became subjects with compromised autonomy and absolute dependence on the health institution. However, the contemporary psychosocial approach utilizes the opposite idea, because efforts are directed to treating the mentally ill as social and historical subjects, that is, as autonomous citizens. This enables the possibility for individuals to create new and constructive dependence and social relations that extend beyond the health services.

The Brazilian psychiatric reform movement proposes structural, social, and legal changes to alter conducts of exclusion. The reform designs the principles and guidelines for mental health care in accordance with the acquisition and promotion of subjects' autonomy. Therefore, it is defined by the social paradigm and, currently, by care that is focused on citizens' autonomy. ${ }^{2,3}$

The study focuses on the social construct of autonomy in subjects in treatment at a type III Psychosocial Care Center, which is a territory-based service. Changes in the theoreticalconceptual and technical-care axes of the psychiatric reform transformed healthcare methods concerning their autonomy and citizenship for subjects with mental disorders and severe psychic distress. From this presupposition, we chose to approach autonomy through psychiatric and mental health nursing, in other words, in these professionals' practice, in the psychosocial context of the theoretical perspective of social constructivism. . $^{4,5}$

The Brazilian Health Policy determines that the Psychosocial Care Centers (CAPS, as per its acronym in Portuguese) be open services, communal, based on a territorial approach, and with the goal of achieving individual therapeutic projects (ITP).

It is worth noting that a singular therapy project (STP) is a tool for the care action plan. It will be distributed among users, families, and the multi-professional team. It comprises a set of interventions that seek to offer comprehensive care to patients.
Thus, in STP, treating diseases is not less important, but it is only one of the actions that aim for comprehensive care from the perspective of the clinic based on the territory of SUS users. ${ }^{2,5,6}$

Psychosocial care centers seek social inclusion through culture, leisure, and citizenship and can contribute to autonomy. ${ }^{6}$ However, this study aims to shed light on the construction of autonomy in the practice of psychiatric nursing care and mental health, considering the current paradigm construct in the field of mental health.

To that end, we defined the following objectives: identify psychiatric nursing practices when mediating the autonomy of social subjects compromised by their psychiatric history; and analyze psychiatric nursing practices focused on the autonomy of subjects who attend a type III CAPS.

Social constructivism is a relational theory tied to a practice that focuses on different types of experiences in the world. This reference allows objections in two categories: linguistic reductionism and relativism. The first emphasizes the language's production of meaning in the collective environment through daily actions. Thus, language produces practice. The second promotes reflections on the effects of what we produce, resulting in an ethical reflection. ${ }^{4}$

Thus, social constructivism enables a permanent transformative dialog about the sources of what we consider knowledge: the real and rational of what is true and good; and everything that is meaningful in life, even in antagonist meanings. Thus, even in conflicts and disagreements in social relations, the constructivist idea is an invitation to dialog. This will enable understanding, analyzing, observing, describing, and reflecting on the traditions inside these life concepts in a specific historiccultural context. ${ }^{4}$

This study is part of the results of the doctoral thesis titled "For a freeing practice: psychiatric nursing in the territory," presented at the graduation program of the Anna Nery Nursing School of the UFRJ. This study verifies the relevance of the autonomy resulting from the territorial practice of psychiatric nursing at the CAPS. The research theme is part of the Research Priorities Agenda in Brazil referring to the item Psychiatric Reform: new actors; their methodologies; and participation strategies.

The theme of dignity and autonomy of the citizens who utilize mental health services has been discussed worldwide ${ }^{7}$ and included in the mental health policies of countries such as Spain, ${ }^{8}$ Portugal, ${ }^{9}$ and Italy, ${ }^{3}$ among others. However, when considering Brazilian psychiatric nursing, the theme has only been addressed indirectly, for example, in discussions of the ethical aspects of user autonomy during treatment, autonomy for the dynamic of therapy devices, or autonomy with families.

\section{METHODS}

This was a qualitative approach study employing convergentcare research (CCR). It differs from other research methods because it brings together research actions and health care actions. ${ }^{10}$ Thus, the research, according to the CCR, happened in 
four stages: conception; instrumentations; scrutiny; and analysis/ interpretation. ${ }^{10}$ In the conception and instrumentation phases, the researchers were immersed in the field, seeking to collect data for full control of the theme under investigation. The field was a CAPS III, in Rio de Janeiro. Participants were seven nurses employed at that CAPS. All of them voluntarily accepted participation in the study and there were no exclusion criteria.

Scrutiny involved the collection and recording of data that provide information, produce scientific constructs around the researched object, and favor the improvement of care offered by nursing. ${ }^{10}$ Data production comprised: participating observation; semi-structured interviews; and educational groups (EG). The three stages were conducted by the first author. Observation brought the author closer to the field, building the research question, and integration with the research participants. It is worth noting that the observation continued in parallel with the other CCR stages. Therefore, the study question was created by converging the research with the territorial care practice of this CAPS III.

Semi-structured interviews (SI) were recorded with the service's seven nurses, with the goal of learning about the nursing practices in that scenario. Research participants were identified as Nur. 1-SI, and continued in the following stages: Nur. 1-1 ${ }^{\circ} \mathrm{EG}$, for example. The $E G$, or convergent care groups ${ }^{10}$ were conducted with the nursing workers of the CAPS III, in agreement with the service's management. Four meetings were carried out with the researched CAPS' seven nurses, lasting 90 minutes each, in the year 2013. The main objective of the EGs was to produce concepts and practices concerning psychiatric nursing work under the territory approach. Educational groups were chosen because of the possibility to reflect on and rebuild the nursing practice in this scenario.

In the first EG, the SI results were presented and there was a discussion about the theme of the psychiatric nursing clinic via the concepts of nursing practices found in the SIs. In the second EG, transcribed concepts from EG-1 were validated and objectives were defined for the conducted practices. In the third EG, the production of meanings resulting from psychiatric nursing's daily practice was addressed. This theoretical production was based on constructivism and immersed in the participants' practical context.

In the fourth EG, there was a subjective assessment ${ }^{10}$ of participants' practices - in other words, the assessment of changes resulting from participation in the EGs: "Has participation in the EGs caused changes in your practices at the CAPS? What changed?"

The analysis and interpretation phase made it possible to give meaning to the findings, to try to contextualize and socialize them toward the transformation of practice. Data analysis was based upon social constructivism, employing the thematic content analysis technique in order to develop the participants' meaning production, ${ }^{4,11}$ in addition to bringing together three crucial processes in the analysis: synthesis; theorization; and transference. ${ }^{10}$ Analysis was conducted by all three authors.
The project was approved by the Human Research Ethics Committee of the City Health Secretariat and the Civil Police of Rio de Janeiro, protocol 23/2013. The participants signed the Free and Informed Consent Form and participated as volunteers after consent from the services' coordination. Limitations were: two participants quit the institution after the second EG, which made their participation impossible in the last two meetings (they participated in the first and second stages of data production fully and participated in the third stage partially); and the study included the production of a single CAPS.

\section{RESULTS AND DISCUSSION}

Initially, the participants listed the nursing practices at the CAPS. Afterward, they conceptualized them and identified the psychiatric nursing clinic. In the analysis, the autonomy of users was emphasized by being implicitly mentioned in the interviews and discussions of the EG's participants.

Autonomy permeates and represents the goal of actions, listed by participants, regarding: care for users' bodies; medication care; small procedures; reference techniques; case discussion; family care; ambiance; care for users in crisis; individual or group therapy workshops; marriage counseling; inter-consultations and home visits; resource seeking and coordination with the territory; embracement inside and outside the CAPS; therapeutic companions; deinstitutionalization support; activities for user empowerment; citizenship activities; trips outside the territory; and assistance for support networks.

The study participants described the nursing practices at the CAPS and in the territory. However, in further discussions, they understood that work was done both from inside the services toward outside and from outside the services toward inside, because this would depend on the dynamic adopted when building the clinic of care for subjects' lives. Psychiatric nursing practices focused on CAPS user autonomy were presented in two categories: 1) Investment in social subjects; and 2) Mediating autonomy.

\section{Investment in social subjects}

Investment in social subjects is conducted through: qualified listening; encouraging hope; time; empathy; and intuition and post-demand care, according to the psychiatric nursing proposal. ${ }^{12}$ Unique therapy projects are built based on attention to life necessities, on the subjective needs of subjects, and on the complexity of the psychosocial approach. However, investment in the autonomy of social subjects was added to this clinic.

Considering the investment in subjects, nurses utilize qualified listening ${ }^{12}$ to learn about the subjects, the context in which they live, and the manifestations of their sufferings. Nurses consider subjects to be social beings. In the moment when nurses learn their patients' life histories, they coordinate themselves in the territory, relate to their families, learn the environment where they spend the most time, their support networks, and their preferences and desires, as expressed in the following speeches: 
"[...] Understanding their history, generally a patient that presents a type of complaint and that, frequently, we consider it necessary to offer them outer-CAPS attention, to understand how they live out there, in which environment they live". Nur. 3 - SI

"He connected with the workshops, but his street movement was noticed because we are out in the territory all the time [...]. He is a guy whose organization was noticed because of the articulations he conducts in the territory". Nur. 1 - SI

"Patients end up putting on paper some of their clinic, of their life histories, of how their lives are at that moment. In this workshop, I try to make them externalize things; I try to find out each one's abilities [...]". Nur. 8 - SI

Research participants seek to learn about the social subject (history and subjectivities) and their territory, because they are contemplating the subjects' autonomy. This demonstrates unconditional faith in humans and the belief that reconstruction is possible in order to resignify issues of life and disease. The clinic goes through the subjects' investment in seeking their own autonomy and liberty, but begins with their desires and their social arrangements. Thus, it is necessary to approximate, observe, and dialog, with the goal of understanding and revealing the subjects' truth. Nurses base their care practices on the elements of their subjects' lives.

Therapy workshops are used to address the users' life experiences and their worldviews. It is through workshops that professionals can interrupt and enhance the dialog with the constructs of living with dignity and citizenship, even with mental disorders or psychic distress. It is important to emphasize that, for constructivism, investigative emphasis lies in explaining the processes through which individuals describe, explain, argue, and build their notions of themselves and of the world in which they live at a given time in history. ${ }^{4}$ In accord with Italian psychiatric reform, the exchanges, the group, and the community activities represent the opportunity to exercise autonomy. ${ }^{3}$

Nursing has as an intervention guideline care based on the concept of a "relationship of help" in nursing practice actions, which are defined by innovation in the use of its know-how. In this construct, care that promotes subjects' autonomy is sought, thus breaking and overcoming relationships of dependence. ${ }^{13}$ In this sense, nursing has as one of its core concepts care for autonomy when it establishes a relationship of help in its practice of health interventions.

Thus, nursing seeks to empower these subjects so that they can reclaim their autonomous condition:

"[...] We try to work daily, to be able to empower, so she can gradually feel safe walking around the territory [...]". Nur. 3 - SI

"[...] The assembly that is not a workshop is a space for user empowerment". Nur. 1 - SI
"How much is enabled by that self-care space making it possible to meet with nurses, hold hands, even banal things. Fantastic stuff for care come out of there[...]". Nur. 3 - SI

\section{"[...] put subjects before diseases". Nur. 3 - 1ํㅡ $E G$}

Empowering ${ }^{3,14,15}$ subjects through words, giving them voice, making it possible for them to give opinions and deliberate about small decisions in the assembly are types of strategies employed to show users with severe mental disorders or with a history of social exclusion that they can re-assume the condition of subjectcitizens. In this context, the empowering process is presented from dimensions of social life at three levels: psychological or individual; group or organizational; and structural or political. Personal empowerment enables the emancipation of individuals with increased autonomy and liberty. The group level enables reciprocal respect and mutual support among group members, promoting feelings of belonging, solidarity practice, and reciprocity, while the structural level favors and enables engagement, co-responsibility, and social participation from the perspective of citizenship. ${ }^{15}$

In social constructivism, the truth in a context can only be established inside a social relationship in the community, because it is in the relationship that truth exists. Thus, outside of it there is no truth, only silence.

Therefore, in constructivism, "Truth results from modes of life shared within a group."4:29 It can be perceived in a study which showed that mediations in convergent groups based on the theoretical division of social constructivism favored the recognition of subjects' autonomy, produced through truths shared between nurse professionals and service users.

It is worth noting that the clinic happens in the meeting through subjective and objective interventions, according to user demands. The content of this intervention is not set beforehand or exclusive to a given professional, but it happens within dialogs.

Autonomy rises as the possibility for subjects to be the protagonists of their own lives, through living: recognizing their limits and possibilities. Even with mental disorders and/or psychic distress, the subjects' potentials for their daily activities must be recognized.

Thus, the study shows that autonomy is stimulated for some subjects, for others it is mediated, and for still others it is negotiated. Thus, nurses choose autonomy and liberty as the bases of care.

Care means, in this perspective, to be with, experiment, and provoke situations in which it is possible to bring light to desires and potentials hidden in histories of the subjects' suffering. Starting with the meeting, the path goes through knowing, intervening, continuing, stimulating, and mediating the subjects' autonomy.

For this, nurses can be convinced to build the process through care actions, as per the following: 
"[...] And we work in tune [...] Nursing is like that, very intimate. It is the most intimate profession on earth[...]". Nur. 1 - SI

"[...] Through bonding, of transferring with patients, professionals can be inside their homes". Nur. 8 - SI

"[...] Sometimes it is hard, even with all your references. Sometimes it is so confusing it gets difficult to conduct care. It is a really delicate situation. It happens all the time in our work". Nur. 9 - 1ํ EG

The perspective of affective care includes nurses as part of relationships. In other words, it demands internal availability to involve and establish bonds. Nurses naturally push for the subjects' success because they believe, invest, and create life projects and hope for their growth. Sometimes the roles of receiving, supporting, stimulating, and helping overcome the roles of limiting, pondering, and negotiating. However, nurses involve other partners in the therapeutic relationship to guarantee the necessary roles for the objectives of the therapeutic project, thus maintaining dynamic care.

It is worth remembering that the constructivist relationship tends to favor forms of dialog from which new realities and new values for care focused on mediating autonomy can emerge. ${ }^{11}$

Psychic distress and mental disorders frequently lead subjects to lose faith and hope in their own existence and to stop believing that their situations can be changed. However, finding meaning for their own lives and achieving control of the situation are a way to minimize suffering. For this, the practices of comprehensive care stimulate subjects' autonomy and can help them resignify the experiences that caused them pain and suffering and attribute new meanings to their own lives.

Care is necessary for those who do not demand it, for those who do not recognize the problem in which they are inserted or who are apathetic. ${ }^{12}$ This process happens in the person-toperson relationship, with affection, continuity, and respect.

Intuition and empathy are tools for closeness, which is employed by caregivers to offer subjects an increase in critical consciousness, remembering meaningful events in their history, or simply expressing some desires. The field of the subjects' desires belongs to them, but awakening memories of past desires and dreams, remembering feelings, and enabling new perceptions contribute to subjects' resignification of their own existence. In any case, the production of this type of care comes from affection.

The production of care and subjectivity for subjects acquires a goal of rebuilding happiness, joy, and vitality as light is brought to daily life, where relationships are built, generally in the person-toperson sphere. From this perspective, care operates in an endless comprehensiveness and its completeness is never reached, because it always gathers more aspects of subjects' existences and microelements in daily life. In this process, language has an important role in a dialogic action of continuous construction. ${ }^{16}$
Technologies developed from investment and affection: ${ }^{17}$ embracement; bonding; co-responsibility; and autonomy. Thus, care means enhancing the condition of social subjects, helping them to satisfy the basic demands of health and citizenship under the psychosocial approach, per these speeches:

"[...] Look, M, let's go buy groceries together. We have to be their secretaries. The psychosis says this; you have to be the psychotic's secretary and, in the territory, this happens a lot". Nur. 1 - SI

"[...] Seek resources, even in the territory, for these people to actually retake control of their lives: social lives; contractuality as citizens (...)". Nur.3 - 1ํEG

"[...] Strengthening Family Clinic care is also our job. And the thing [case discussion] of resolution in the Family Clinic. Sometimes, it is about presenting them as "our child" so that they comply". Nur. 16 and 9 - $1^{\circ} E G$

"On a walk in the territory to seek bamboo for decorating the June celebration [...] user $G$ wanted to climb a tall hill to help in cutting bamboo. The workers monitoring the activity told him he should not do it, except for the nurse, who was emphatic when stating: " $G$, you can; $G$, go help them." The user climbed the hill and cut the bamboo." Observation June - 2013.

For research participants, caring for life's necessities means helping subjects in their lives, handling each case individually, being their secretary, directing, encouraging responsibility, reinserting them into life, seeking partners for the territory, strengthening support networks, and seeking resources in the territory. Regarding the social subject, care must consider the subject in the world, as a citizen who is aware, capable to selfcare and enjoy the possibilities offered by society. Participants must seek resources in the territory or find hidden resources, work along with the community network to strengthen the SUS's subject, including marriage support and promotion of health in their coverage area.

The meaning of care for subjects' autonomy is created along with the relationship between workers and users. This breaks with the hermeneutic circle by not focusing on the meaning inside the mind, but instead focusing on this meaning in the relationship of subjects with their social networks and the territory's resources. ${ }^{4}$ Social constructivism believes that "the forms of negotiated understanding are of critical importance in social life, in the sense that they are fully connected to other activities in which individuals participate."11:306

\section{Mediating autonomy}

Considering the subjects' liberty in life, nurses employ the construct of mediated autonomy as a way to support the construction of the subjects' liberty. This construct is based on 
investing in cared-for subjects so that they build their own story, freeing themselves of dependence, making new relationship networks. In short, they make their own choices and take responsibility for them as the citizens and social beings that they are. This is the opposite of the guardianship in the hospitalcentered model-mediated autonomy. Mediated autonomy is personal advisory for subjects, gathering safety, support, and protection without removing control over their own lives, because these belong to the subjects, as expressed in the speeches:

\section{"[...] The hospital safeguards, and we try to do the exact opposite". Nur. 7 - 1ํE $E$}

"[...] It is true user monitoring - in the service, when they are going through a crisis, in the community, wherever, going to the bank, grocery shopping, trying to produce autonomy, mediating some relationships. I had a patient that owed to a lot of businesses. She owed an awful lot to the butcher; she owed everybody and I started going to her house and going with her to the butcher and tried to mediate the relationship with the butcher, who was adding undue products to her bill. So, being able to do this work with her in the monitored territory, mediate the relationships". Nur. 3, 6 and 7

"[...] Actually, it will also contribute to autonomy in the sense that you are trying to advise individuals, contributing to finally give them protection, support, and safety". Nur. 1 - 1ํㅡ

"[...] User $M$ reported to the service looking unkempt, with precarious hygiene, angry behavior, and hostile to other users. In the opening meeting for the shift, the nurse talked about how this behavior generally is associated with abandonment of drug therapy and it was collectively decided to call her family and negotiate the possibility of extending her permanence until 8 p.m. for one week in order to prevent a possible crisis". Observation May, 2013

Mediated autonomy happens at various levels. For example, a user in the process of deinstitutionalization demands more advising, protection, and proximity, while others with more social skills need less close assistance. It is expected that these subjects, at some point, stop needing this professional monitoring.

Mediated autonomy means encouraging subjects to empower themselves for their whole lives, from small choices to more elaborate life projects. It is a complex process because it involves psychosocial rehabilitation - in other words, building new skills and identities for life in society. ${ }^{18}$

Thus, to increase subjects' autonomy, nurses focus on mediating relationships, and these relationships contribute to social life and identity construction. Work for CAPS users is a complex social relationship that needs to be considered, planned, and mediated according to the subjects' possibilities. However, it becomes possible when subjects have skills in social relationships, to both initiate it or maintain it, for example. These possibilities for autonomy are discussed, conducted, and mediated in the users' Unique Therapeutic Project until the goal is reached.

Strategies for mediated autonomy include home visits, night sheltering, therapeutic monitoring, periodic assessment through individual attention, circulating in the territory, attention to families, case discussion with the team, therapeutic workshops, therapeutic groups, and defining tasks with increasing complexity, among others. As subjects acquire autonomy in life, they increase their liberty and their responsibility for selfmanagement. However, nurses mediate this process through advising and monitoring of subjects' lives through therapeutic exchanges during day-to-day care in the CAPS III.

As people develop, new demands and new resources arise. Thus, users use their liberty to express themselves and travel the territory, learn the social rules, enjoy benefits, and share solidarity and identities. The top resource hidden in the territory is this possibility to be in social relationships.

A study ${ }^{19}$ on crisis care in the territory shows that liberty, reciprocity, contractuality, and responsibility for care, demonstrated by the ability to accommodate to a crisis using the territory's devices, are the new meanings that are so necessary for contemporary mental health services.

From this aspect, thinking about life history, the context where subjects live, their health problems, their emergent needs, their autonomy, and so on are part of a set of processes to build life promotion projects. At the same time these data show the complexity and severity of needs of attended users. They also bring satisfaction with the signs of users' well-being in the relationship between service and territory.

Mediating autonomy means expanding the possibilities for exchanging and resignifying life, which were expressed in the speeches:

"[...] There is also the case of D. We are working with deinstitutionalization; she stayed in the clinic for 17 years [...] we are conducting a passage process, so she can come back to living here. Even if we can take care of her, she will not be able to just walk around here like the local residents. We have to be careful with the issue of protection, all the while also stimulating autonomy". Nur. 1 - $1^{\circ} E G$

"[...] There are the trips: we go along with a technician team. If some patients with more difficulties go, we give them a technician, who will basically be the patient's therapeutic companion, to help them with this kind of interaction with their environment and leaving the services, making all this a little more open". Nur.3 - SI

It is not possible to talk about care from the psychosocial perspective without considering the culture and way of life. As such, the territory and the families' histories are important for this therapeutic construct. Social constructivism analyzes 
the production of meanings, considering the collective in order to understand each context in its unique features. Health production is considered the responsibility of everyone involved, with practices focused on autonomy, co-responsibilities, comprehensiveness, the creation of bonds, and the meanings of health in which the community context circulate, into which users of health services are inserted. ${ }^{20}$

In this context, the idea of autonomy construction is highlighted as the reflection of everyone involved in the autonomous condition of the users. This is stimulated along with the territory, and it also strengthens freeing practices committed to citizenship. These practices include community activities, dialog spaces (users, family, and community), professional experimentation through work in interdisciplinary teams, and case discussions, among others.

The thresholds between liberty, support, and protection deserve special attention when mediating autonomy. As such, dialog becomes fundamental, because there are no established truths. There is a path to be built from the presupposition that all men are free and autonomous. However, the ideas of democracy and citizenship have defined the first steps toward autonomy.

However, to reach the therapeutic objective, it is necessary to handle and dialog with the subjects' potentials to enable the recognition of their needs, considering the development of conditions that are increasingly better and that might allow the management of their lives and increase their possibilities for choices. Thus, autonomy means increasing the capacity to understand and act for oneself and on the world in the exchanges offered by life.

The degree of autonomy is measured by the capacity for self-care, for understanding the health-disease process, for using power, and for establishing commitment and contracts with others. ${ }^{17}$

The trips, the therapeutic companion, the support in life represent the commitment of nurses to subjects under their care. Such posture demonstrates ethical commitment, enabling the exercise of citizenship through autonomy mediation. The notion of autonomy building as the capacity for reflection is stimulated along with the collectives, promoting liberty practices that are committed to others, considering that the exercise of autonomy is conducted inside relationships. ${ }^{20}$

In the last EG, when participants were asked to talk about what changed in their practice, after extended discussions they concluded that care in isolated practices stimulated subjects' autonomy, but after the EG, they consciously invested in and mediated autonomy. In other words, the discussion within the psychiatric nursing clinic enabled participants to reflect on the practices and objectives of care for social subjects in a way that cleared up and modified practice.

\section{CONCLUSION AND IMPLICATIONS FOR PRACTICE}

Psychiatric nursing clinics invest in their subjects' autonomy, because the subjects believe they will achieve stronger health through subjective exchanges. Autonomy will be proportional to their most intimate choices and, in practice, will increase their social awareness, protagonism, and respect for liberty and autonomy.

The practices of psychiatric nursing related to the autonomy of the users of the researched CAPS permeate and represent the goal of any action executed inside or outside the service, be it in body care for users, medication care, or care for users in order to address their own lives. Participants invest in social subjects, seek the social resources for their demands, and stimulate selfmanagement and mediated autonomy, because nurses believe that users can be more autonomous.

All actions are discussed, negotiated, and built with users, families, teams, health networks, and territories. Nurses assert that there are no truths or prior knowledge, because it is in daily practice that decisions are based. Moreover, this involves knowledge and the rules of the territory. Participants affirmed that the research and the EGs contributed to reflections and theoretical constructs related to psychiatric nursing from the territorial perspective. They also emphasized that this contributed to conducting the same actions with awareness of the investment in users' autonomy.

In citizens' autonomous and free condition is the beginning of the path toward dignity for users with a psychiatric history. To light this path, this study suggests further research on social constructivism (linguistic and meaning production), starting with mental health services users, their constructs, and their demands for autonomy.

\section{REFERENCES}

1. Paim L. Impactos produzidos pela Pesquisa Convergente Assistencial In: Trentini M, Paim L. Pesquisa convergente assistencial: um desenho que une o fazer e o pensar na prática assistencial em saúdeenfermagem. $3^{a}$ ed. Porto Alegre: Moriá; 2014. p.71-92.

2. Paranhos-Passos F, Aires S. Reinserção social de portadores de sofrimento psíquico: o olhar de usuários de um Centro de Atenção Psicossocial. Physis [Internet]; 2013 [cited 2016 Jul 06]; 23(1):13-31. Available from: http://www.scielo.br/pdf/physis/v23n1/02.pdf http:// dx.doi.org/10.1590/S0103-73312013000100002

3. Junqueira AMG, Carniel IC. Olhares sobre a loucura: os grupos na experiência de Gorizia. Rev SPAGESP [Internet]. 2012 [cited 2016 Jul 07]; 13(2):12-22. Available from: http://pepsic.bvsalud.org/scielo. php?script=sci_arttext\&pid=S1677-29702012000200003\&lng=pt

4. Gergen MM, Gergen KJ. Construcionismo social: um convite ao diálogo Rio de Janeiro: Instituto Noos; 2010. 115p.

5. Yasui S, Luzio CA, Amarante P. From manicomial logic to territorial logic: Impasses and challenges of psychosocial care. J Health Psycho [Internet]. 2016 [cited 2016 Jul 07]; 21(3):400-408. Available from: http:// journals.sagepub.com/doi/10.1177/1359105316628754 http://dx.doi. org/10.1177/1359105316628754

6. Grigolo TM, Pappiani C. Clínica ampliada: recursos terapêuticos dos centros de atenção psicossocial de um município do norte de Santa Catarina. Cad Bras Saúde Mental [Internet]. 2014 [cited 2016 Jul 07] 6(14):1-26. Available from: http://incubadora.periodicos.ufsc.br/index. php/cbsm/article/viewFile/2903/3948

7. WHO QualityRights tool kit Assessing and improve quality and human rights in mental health and social care facilities. Geneva: World Health Organization; 2012. Available from: http://apps.who.int/iris/ bitstream/10665/70927/3/9789241548410_eng.pdf 
8. Desviat M. La reforma psiquiátrica 25 años después de la Ley General de Sanidad. Rev Esp Salud Publica [Internet]. 2011 Oct [cited 2016 Jul 26]; 85(5):427-36. Available from: http://scielo.isciii.es/scielo. php?script=sci_arttext\&pid=S1135-57272011000500002

9. Lopes F, Oliveira K, David M, Rebelo R. "Projeto Mensanus": ganhos em saúde mental. Rev Port Enferm Saúde Mental [Internet]. 2014 Jun [cited 2016 Jul 07]; (11):55-60. Available from: http://www.scielo.mec.pt/scielo. php?script=sci_arttext\&pid=S1647-21602014000200008\&lng=pt

10. Trentini M, Paim L. Pesquisa convergente assistencial: um desenho que une o fazer e o pensar na prática assistencial em saúde-enfermagem. $3^{\underline{a}}$ ed. Porto Alegre: Moriá; 2014

11. Gergen KJ. O movimento do construcionismo social na psicologia moderna. Rev Inter Interdisc INTERthesis [Internet]. 2009 Jan/Jul [cited $2016 \mathrm{Jul}$ 07]; 6(1):299-325. Available from: https://periodicos. ufsc.br/index.php/interthesis/article/view/10976 http://dx.doi. org/10.5007/1807-1384.2009v6n1p299

12. Alves M, Oliveira RMP. Enfermagem psiquiátrica: discursando o ideal $e$ praticando o real. Esc Anna Nery [Internet]. 2010 Mar [cited 2016 May 17]; 14(1):64-70. Available from: http://www.scielo.br/pdf/ean/v14n1/ v14n1a10.pdf http://dx.doi.org/10.1590/S1414-81452010000100010

13. Oliveira RM, Furegato ARF. Assistance relation with psychiatric patient: beyond the medical paradigm. SMAD, Rev Eletrônica Saúde Mental Álcool Drog [Internet]. 2012 Jun [cited 2016 Jul 07]; 8(2):8793. Available from.: http://pepsic.bvsalud.org/scielo.php?script=sci arttext\&pid=S1806-69762012000200006\&lng=pt\&tIng=en

14. Alves TC, Oliveira WF, Vasconcelos EM. A visão de usuários, familiares e profissionais acerca do empoderamento em saúde mental. Physis [Internet]. 2013 [cited 2016 Jul 07]; 23(1):51-71. Available from: http:// www.scielo.br/pdf/physis/v23n1/04.pdf http://dx.doi.org/10.1590/ S0103-73312013000100004
15. Kleba ME, Wendausen A. Empoderamento: processo de fortalecimento dos sujeitos nos espaços de participação social e democratização política. Saude Soc [Internet]. 2009 Dec [cited 2016 May 17]; 18(4):73343. Available from: http://www.scielo.br/pdf/sausoc/v18n4/16.pdf http:// dx.doi.org/10.1590/S0104-12902009000400016

16. Martines WRV, Machado AL. Produção de cuidado e subjetividade. Rev Bras Enferm [Internet]. 2010 Apr [cited 2016 May 17]; 63(2):32833. Available from: http://www.scielo.br/pdf/reben/v63n2/25.pdf http:// dx.doi.org/10.1590/S0034-71672010000200025

17. Jorge MSB, Pinto DM, Quinderé PHD, Pinto AGA, Sousa FSP Cavalcante CM. Promoção da Saúde Mental - Tecnologias do Cuidado: vínculo, acolhimento, co-responsabilização e autonomia. Ciênc Saúde Coletiva [Internet]. 2011 Jul [cited 2016 May 16]; 16(7):3051-60 Available from: http://www.scielo.br/pdf/csc/v16n7/05.pdf http://dx.doi. org/10.1590/S1413-81232011000800005

18. Saraceno B. A cidadania como forma de tolerância. Rev Ter Ocup Univ São Paulo 2011 Maio/Ago [cited 2016 May 16];22(2):93-101. Available from: http://www.revistas.usp.br/rto/article/view/14126 http://dx.doi. org/10.11606/issn.2238-6149.v22i2p93-101

19. Willrich JQ, Kantorski LP, Chiavagatti FG, Cortes JM, Antonacci $\mathrm{MH}$. The meanings constructed in the attention to a crisis in the territory: the Psychosocial Care Center as a protagonist. Rev Esc Enferm USP [Internet]. 2013 Jun [cited 2016 May 17]; 47(3):657-9. Available from: http://www.scielo.br/pdf/reeusp/v47n3/en_00806234-reeusp-47-3-00657.pdf http://dx.doi.org/10.1590/S0080623420130000300019

20. Cadoná E, Scarparo H. Construcionismo social na atenção básica: uma revisão integrativa. Ciênc Saúde Coletiva [Internet]. 2015 Sep [cited 2016 May 16]; 20(9):2721-30. Available from: http://www.scielo. br/pdf/csc/v20n9/1413-8123-csc-20-09-2721.pdf http://dx.doi. org/10.1590/1413-81232015209.13552014 